\title{
Arsenic Exposure to Fish and Shellfish Consumption among Community in Makassar, Indonesia
}

\author{
Musfirah $^{1}$, Sri Damayanty ${ }^{2}$ \\ ${ }^{1}$ Department of Public Health Science, Universitas Ahmad Dahlan, Yogyakarta, Indonesia \\ ${ }^{2}$ Department of Public Health, Institute of Health Science Avicenna, Kendari, Indonesia
}

\begin{tabular}{l}
\hline Article Info \\
\hline Article history: \\
Received Jul 29, 2016 \\
Revised Sep 20, 2016 \\
Accepted Sep 26, 2016 \\
\hline
\end{tabular}

Keyword:

Arsenic

Environmental health risk analysis

Gafrarium tumidum shellfish

Leiognatus equulus fish

\begin{abstract}
Fish and shellfish contaminated by Arsenic (As) heavy metals from people activity discharge into the coast. Coastal community was exposure risk by As due to consumption of marine products. This study aimed to determine of human health risks level who consume fish and shellfish that contain As in Kaluku Bodoa and Untia coastal, Makassar. This research designed by observational and Environmental Health Risk Analysis (ERHA) approach. Human sample were 49 people and 8 environmental samplesthat selected based on certain criteria. Data collected through environmental assestment, interview and anthropometric data measurement. Data analyzed with ERHA methods. The results showed that the highest mean As levels found in Leiognatus equulusfishi.e. $1.589 \mathrm{mg} / \mathrm{kg}$ and Gafrarium tumidumshellfishi.e. $4.244 \mathrm{mg} / \mathrm{kg}$ of Untia coastal. The mean level of the carcinogenic risk for fish and shellfishconsumptionwere unacceptable because they contain As that demonstrated value of more than exponent 4 (ECR $>$ E- 4$)$ and non-carcinogenic risk mean level was value of more than 1 (RQ>1). Fish and shellfish consumption considered unsafe and will impact health problems for the community. Community should be restrict the frequency and amount of fish and shellfish consumption.
\end{abstract}

Copyright $(0) 2016$ Institute of Advanced Engineering and Science. All rights reserved.

\section{Corresponding Author:}

Musfirah,

Department of Public Health,

Universitas Ahmad Dahlan,

Jl. Prof Soepomo, Janturan, Warungboto, Yogyakarta, Indonesia.

Email: firah.musfirah014@gmail.com

\section{INTRODUCTION}

Heavy metal pollution cases was make the world community shocked because arsenic contamination. Arsenic poisoning impact for 85 million people due to consumption of arsenic-contaminated drinking water in the coastal areas of Bangladesh. The mass poisoning case reports of environmental pollution was the biggest recorded in world human history in the 20th century. Drinking water levels of $20 \mathrm{mg} / \mathrm{L}$ has been impact for human health problems. Therefore, WHO establishes the levels of As in drinking water that allowed to less than $10 \mathrm{mg} / \mathrm{L}$ [1].

Several studies in the UK also found arsenic levels in seafood like oysters, shrimp and fish. Samples of aquatic biota were examined. It was found arsenic levels in the sponge $(8-24 \mathrm{mg} / \mathrm{kg}$ wet weight), mollusks (1-68 mg/kg wet weight), crustaceans $(10-79 \mathrm{mg} / \mathrm{kg}$ ). While the fish varies, i.e. $2-15 \mathrm{mg} / \mathrm{kg}$ wet weight or $2-25 \mathrm{mg} / \mathrm{kg}$ dry weight content was quite high and indicated may be distributed to the humans who consume them, and accumulated in the body to be carcinogenic to humans [2].

Previous study related to heavy metals pollution from the north east of Bengal Bay, India showed toxic levels of heavy metal mercury ( $\mathrm{Hg}$ ) and arsenic (As) specified in the muscle tissue of six species of marine fish were collected. Arsenic levels were in the range of 0.02 to $2.34 \mathrm{mg} / \mathrm{g}$ dry weight. United State of 
America set the levels of As that can be consumed in seafood less than $0.04 \mathrm{mg} / \mathrm{day}$, while the number of total As levels that can be consumed at $0.2 \mathrm{mg} /$ day [3].

Arsenic pollution in Buyat Bay, North Sulawesi Minahasa Regency has also been an environmental case in Indonesia. This occurs due to the location of tailings disposal which empties into the ocean waters, themean level of As in the fishwas $1,37 \mathrm{mg} / \mathrm{kg}$ total levels in Buyat Bay exceed the quality standards set by Food and Drug Administrationof Indonesia which equal to $1 \mathrm{mg} / \mathrm{kg}$ [4]. Arsenicabsorbed by $90 \%$ in the body that stored in the liver, kidneys, digestive tract wall, spleen and lungs. It also stored in small amounts in the hair and nails as well as undetected for a long time, a few years after chronic poisoning [5].

Results study have also been conducted in Buyat North Sulawesi [6], there were found arsenic levels in water $0.098 \mathrm{mg} / \mathrm{L}$, and fish of $3.867 \mathrm{mg} / \mathrm{kg}$. Furthermore, the acquired diagnosis cases of disease in the population showed not strong dose-response relationship arsenic causes skin lesions [6]. These results were consistent with high concentrations of arsenic foundedwhich 25 wells inspected the water, the number of cases as many as 54 people who suffer from disorders of the skin (keratosis or hyperkeratosis). The results obtained, $90 \%$ of water wells polluted Buyat village with minimum concentrations $(0.0063 \mathrm{mg} / \mathrm{l})$, maximum $(0.1040 \mathrm{mg} / \mathrm{l})$ and the mean $\pm \mathrm{SD}(0.040 \pm 0.030 \mathrm{mg} / \mathrm{l})$. Health risk (RQ) has exceeded 1 , duration time was 1.5 years and a maximum consumption rate of $53 \mathrm{ml} /$ day/person weighing $35 \mathrm{~kg}$. Based on these data findings, Buyat community should not drink water from wells exceeds $53 \mathrm{ml} /$ person/day as an environmental health risk management [7].

The Environmental Protection Agency (EPA) has determined that the metal arsenic was harmful to human health and it can lead to non-carcinogenic and carcinogenic illness. Inorganic arsenic can cause skin cancer, lung, liver and bladder. High levels of exposure can cause the death of human, while long-term exposure can cause darkening of the skin, warts on the palms, soles, and torso [8-9].

Heavy metal pollution in the waters at the Losari Makassar (near Makassar Golden Hotel) and Losari (front of Fort Rotterdam) sampling point has exceeded safe limits. In September 2012 the results obtained successively at the two points [i.e. $0.0081 \mathrm{mg} / \mathrm{L} ; 0.0372 \mathrm{mg} / \mathrm{L} ; 0.0185 \mathrm{mg} / \mathrm{L}$ ] and $[0,0045 \mathrm{mg} / \mathrm{L}$; $0.0659 \mathrm{mg} / \mathrm{L} ; 0.0141 \mathrm{mg} / \mathrm{L}]$. Heavy metal levels have exceeded the standard of South Sulawesi Governor Regulation No. 69 Year 2010 regarding Standard and Environmental Damage Criteria Appendix No. I.c.2. Sea Water Quality Standard for Marine tourism [10], wherein $0.002 \mathrm{mg} / \mathrm{L}$ for the metal mercury $(\mathrm{Hg})$, $0.002 \mathrm{mg} / \mathrm{L}$ for Hexavalent Chromium (Cr VI), and $0.005 \mathrm{mg} / \mathrm{L}$ for lead (Pb) [11].

Characteristics of metals in an aquatic environment were highly dependent on the speciation of metals. It had affected the presence of these metals in biological tissues (bioavailability) and toxicity to biota, transportation and mobilization, as well as interaction with sediment or soil [12]. Heavy metals settle to the sediment has a residence time to thousands years while the inside of living organisms, heavy metals will be concentrated through the bioaccumulation process. Heavy metals can presence into the body organism in three ways items, namely food chain, gills and diffusion through the skin surface. Thus, indicators of heavy metal pollution in coastal waters use the sediment and marine life that presencein the waters around the sea [13-14].

Presence of heavy metals in coastal Makassar will be lowering the environment quality and toxic to marine life even to humans. Types of marine life such as fish and shellfish consumed by community because of the high protein content. The mussels were found in the coastal area and sold by fishermen on the edge. In addition, taffordable prices by the community. The high level of fish and shellfish consumption which metal contaminants impact to public health in acute and chronic disease. Metal accumulated in marine life and human tissue [14-16].

The coastal community as apeopleaffected therisk of heavy metal pollution in the waters. There were 14 districts in Makassar city, but the selected area just two sub-districtwhich have coastal community, potentially exposed to arsenic due to industrial activities, maritime integrated region, yag agricultural pesticides and commercial fertilizers namely Kaluku Bodoa Coastal in Tallo sub-district and Untia Coastal in Biringkanaya sub-district.

Based on data about presence of heavy metals in Makassar, a source of heavy metal pollution, as well as the nature of the carcinogenic and non-carcinogenic in humans, the researchers interested to measure the levels of arsenic contained in fish and shellfish consumed by Kaluku Bodoa and Untia coastal Community. Observasional study was using Environmental Health Risk Analysis approach related to Arsenic (As). These approach become limited research studyand never been done before in this coastal region. This study aimed to determine the health risk of arsenic contamination in fish and shellfish due to seafood consumption for Kaluku Bodoa and Untia coastal community in Makassar City. 


\section{RESEARCH METHOD}

\subsection{Research design}

This type of research was an observational study with an Environmental Health Risk Analysis (EHRA) approach which risk factors were measured at the same time to provide a magnitude prediction of the health risks caused by Arsenic in fish and shellfish.

\subsection{Location and time research}

The study conducted on May-June 2014 in Makassar coast, sampling site are Tallo District (Kaluku Bodoa Coastal) and Biringkanaya (Untia Coastal), South Sulawesi, Indonesia. The selected location based on the consideration that the coastal areas had experienced sedimentation and water pollution from two rivers namely, Jeneberang and Tallo river. There werealso a variety of activities that potentially contaminate aquatic environments such as industrial, maritime integrated area, residential, hospitality and agricultural activities.

\subsection{Population and sample}

The environmental population were fish and shellfish in the Makassar coastal. The sample in this study taken from Kaluku Bodoa and Untia Coastal. The tissue samples of fish/shellfish that has been obtained,then taken to the laboratory and Research Center for Food Technology of Marosas laboratory analysis of Arsen. Sampelanalyze was using AES (Atomic Emwassion Spectroscopy).

The human population was all the fisherman who live in Untia and Kaluku Bodoa Coastal area. The sample in this study was a fishermen population as much as 49 people. Sampling was done by proportional random sampling method.

\subsection{Data analysis}

This study used Environmental Health Risk Analysis (ERHA) and Excel programme. Environmental health risk analysis carried out by the risk characterization procedures which calculated using the formula:

$$
R Q=\frac{I}{R f D}
$$

Annotation :

RQ : Risk Quotient (Non-carcinogenic Risk characterization)

RfD : Analysis of dose-response

I : Intake

The level of health risks for carcinogenic effects expressed in notation Excess Cancer Risk (ECR). To characterize the risk for carcinogenic effects calculation by folding intake with Slope Factor (SF). The formula for determining the ECR was as follows:

$$
E C R=\operatorname{Ink} \times S F
$$

Annotation :

$\mathrm{ECR}=$ Excess Cancer Risk (carcinogenic risk characterization)

$\mathrm{SF}=$ reference value risk agent with carcinogenic effects $(\mathrm{mg} / \mathrm{kg} / \mathrm{hari})$

I $\quad=$ Intake $(\mathrm{mg} / \mathrm{kg} / \mathrm{hari})$

Arsenic has a value of SF according to international standards that was equal to $1.5 \mathrm{mg} / \mathrm{kg} / \mathrm{day}$, equivalent to the reference dose $(0.0001 / \mathrm{SF}=0.0001 / 1.5=6.66667 \mathrm{E}-05)$. The risk characteristics expressed by the level of risk (Risk Quotient "RQ") for the effects of non-carcinogenic wasdividing between intake (I) and refrence dose (RFD) while the carcinogenic risk levels expressed in notation Excess Cancer Risk (ECR), which was the multiplication of intake (I) and the slope factor (SF). Risk exists and needs to be controlled if RQ $>1$ and ECR > E-4 [17].

\section{RESULTS AND ANALYSIS}

The results of this study showed that the risk of Arsenic in location study areas wasvery high levels because the fish and shellfish consumption as well as supported by the characteristics of respondents who contribute to occur the health problems. 


\subsection{Distribution of respondents characteristics in the Kaluku Bodoa and Untia Coastal}

The distribution of respondents characteristics in the Kaluku Bodoa and Untia Coastal can be showed below in Table 1 . The number of fishermen who frequently eat fish and shellfish catched of about 49 people with the majority age and length of stay for respondents both in the range of 30-40 years with a percentage of $57.1 \%$. Table 1 also shows that respondents who had elementary education as much as $49 \%$. Health problems were often experienced by the majority of respondents are skin complaints of itching and diarrhea as much as $28.6 \%$ of respondents to the nature of the disease constantly as much as $95.9 \%$. The efforts treatment of the majority respondents was doing their own treatment. Community should not be allowed if the symptoms have appeared already. We recommend that the respondent should check to a doctor theirhealth or the nearest healthcare. Low education level of respondents lead to a lack of awareness or initiatives to report health complaints to health services. Thus, the community decided to treat themselves to a generic drug with dose not fit even ignoring complaints. Major community was consider a common disease that can heal itself without further intervention.

Table 1. Distribution of Respondents Characteristics in the Kaluku Bodoa and Untia Coastal

\begin{tabular}{|c|c|c|}
\hline Variable & $\mathrm{N}$ & Percentage $(\%)$ \\
\hline \multicolumn{3}{|l|}{ Age } \\
\hline a. $<30$ years old & 8 & 16.3 \\
\hline b. $30-40$ years old & 28 & 57.1 \\
\hline c. $>40$ years old & 13 & 26.5 \\
\hline \multicolumn{3}{|l|}{ Level of Education } \\
\hline a. Not graduated elementary school & 6 & 12.2 \\
\hline b. Elementary school & 24 & 49.0 \\
\hline c. Junior High School & 17 & 34.7 \\
\hline d. Senior High School & 2 & 4.1 \\
\hline \multicolumn{3}{|l|}{ Length of stay } \\
\hline a. $<30$ year & 8 & 16.3 \\
\hline b. $30-40$ year & 28 & 57.1 \\
\hline c. $>40$ year & 13 & 26.5 \\
\hline \multicolumn{3}{|l|}{ Health problems } \\
\hline a. Skin (irritation/itching) & 14 & 28.6 \\
\hline b. Muscle ache & 10 & 20.4 \\
\hline c. Asthma & 2 & 4.1 \\
\hline d. Rheumatism & 5 & 10.2 \\
\hline e. Cough & 4 & 8.2 \\
\hline f. Diarrhea & 14 & 28.6 \\
\hline g. Others..etc. & 0 & 0 \\
\hline \multicolumn{3}{|l|}{ Characteristic of disease } \\
\hline a. Cronic & 47 & 95.9 \\
\hline b. Recurrence & 2 & 4.1 \\
\hline \multicolumn{3}{|l|}{ Treatment efforts } \\
\hline a. Self-medication & 28 & 57.1 \\
\hline b.To the health service & 13 & 26.5 \\
\hline c. To witchdoctor & 8 & 16.3 \\
\hline
\end{tabular}

Source : Primary Data

Health problems according to Table 1 that occur such as skin complaints of itching and diarrhea that are constantly can be early symptoms due to the nature toxic of arsenic that contaminated fish and shellfishwhich consumed by Kaluku Bodoa and Untia coastal community. It related consistent with study that successfully confirmed to the diagnosis cases and arsenicexposure assestment in fish provided important data about dose response of arsenic can cause skin lesions that exposure to ingestion from Buyat residents amount to $0.011 \mathrm{mg} / \mathrm{kg}$ wet weight and the discovery of the high value of the Target Hazard Quotient (THQ) amount to 0.365 [6-7].

\subsection{Levels of arsenic (As) from fish and shellfish in Kaluku Bodoa and Untia Coastal}

The fish samples of this research founded in Kaluku Bodoa and Untia coastal areas that consumed by local people or community were Siganus sp. and Leiognatus equulus while species of mussels samples were Anadara grandis and Gafrarium tumidum. The results study from Table 2 shows that the higher mean arsenic levels in fish and shellfish found in Untia than Kaluku Bodoa coastal. The mean Arsenic levels of Leiognatus equulusfish was $1.589 \mathrm{mg} / \mathrm{kg}$ and Gafrarium tumidum shellfish of $4.244 \mathrm{mg} / \mathrm{kg}$ Arsenic. 
Table 2. Levels of as Metals from Fish and Shellfish in the Kaluku Bodoa and Untia Coastal

\begin{tabular}{llc}
\hline \multicolumn{1}{c}{ Location } & \multicolumn{1}{c}{ fish and shellfish species } & As $(\mathrm{mg} / \mathrm{kg})$ Level \\
\hline \multirow{2}{*}{ Kaluku Bodoa } & Fish & \\
& Siganus sp. & 1.627 \\
\multirow{3}{*}{ Untia } & Mean & 1.327 \\
& Leiognatus equulus & 1.477 \\
& & 1.249 \\
\multirow{2}{*}{ Kaluku Bodoa } & Mean & 1.928 \\
& Shellfish & 1.589 \\
\multirow{2}{*}{ Untia } & Anadara grandis & 3.708 \\
& & 2.527 \\
& Mean & 3.118 \\
& Gafrarium tumidum & 3.987 \\
& & 4.501 \\
& Mean & 4.244 \\
\hline
\end{tabular}

Source : Primary data

The results on Table 2 also shows that the mean levels of arsenic in fish and shellfish was higher in Biringkanaya Sub-district precissely in the Coastal Untia than Tallo Sub-district. The high levels arsenic in Untia coastal due to land had use as paddy fields and plantations, and also as the shipping busy traffic area. Pesticides and fertilizers used by farmers contributed greatly high levels of heavy metals arsenic discharged into the environment and eventually empties into the sea [19]. Presence of heavy metals in fish and shellfish might indicate health problems to humans through the fish and shellfish consumptions. Health problems caused by heavy metals become systemic effects with clinical symptoms appear after consuming for a long time. Based on the results of fish and shellfish samples assestments in Table 2, Kaluku Bodoa and Untia were categorize unsafe for consumption by the public because it was above the maximum threshold allowable to 1 $\mathrm{mg} / \mathrm{kg}$ Arsenic for food like seafood [4], [18].

Heavy metals founded to be higher level in shellfish than fish because the tendency of all types of shellfish to store or accumulate heavy metals for a long period time and patterns of movement are limited when compared to fish. The other study showed that the order of sequence the higher cadmium levels found in the Lake Sentani was a row of benthic (Plectropomus Leopardus) $>$ pelagic fish (Pilchards) $>$ Shellfish (Anadara trapecia), the maximum value that still exist, namely $(4.34>2.89>2.40) \mathrm{mg} / \mathrm{kg}$ wet weight [20].

\subsection{Carcinogenic risk (ECR) and non-carcinogenic risk (RQ) level due to heavy metal exposure through consumption of fish and / or shellfish}

Carcinogenic risk level was expressed in exponent without units (for example: 1,3E-4). The risk level was being acceptable or safe when ECR $\leq$ E-4 $\left(10^{-4}\right)$ or expressed by ECR $\leq 1 / 10,000$. The risk level was being unacceptable or unsafe when ECR $>$ E-4 $\left(10^{-4}\right)$ or expressed by ECR $>1 / 10,000$. Non-carcinogenic risk level was expressed in terms of Risk Quotient (RQ). If $R Q \leq 1$, it means exposure remained below normal limits and the people who consume the shellfish and fishwithin still safe limits from a health risk by arsenic exposure throughout his life. If $\mathrm{RQ}>1$, it means that the exposure was above normal limits and people who eat fish and shellfish that pose a health risk by arsenic exposure throughout his life [21]. To determine the level of risk, it was necessary to include the intake value to see how much daily intake of fish and shellfish consumption that contain heavy metals than the reference dose (As=0.0003 mg/kg/day). Exposure duration default value used was 30 years [18].

The results study on Table 3 shows that the carcinogenic risk level (ECR) and non-carcinogenic risk level (RQ) consumption of fish and shellfish in the coastal city of Makassar residents. The means level of carcinogenic risk (ECR) fish and shellfish consumption contain arsenic (As) from Kaluku Bodoa and Untia coastal which value more than exponent 4 (ECR>E-4) that mean value in Kaluku Bodoa i.e. 1.19E-03 for Siganus sp., 2.20E-03 for Anadara Grandis and 1.10E-03 for Leioghnatus equulus and 2.31E-03 for Gafrarium tumidum in Untia. The mean level of Risk Quotient (RQ) for fish and shellfish consumption contain arsenic contamination was value more than 1 (RQ>1) that mean value in Kaluku Bodoa i.e. 6.2 for Siganus sp; 11.42 for Anadara Grandis and 5.71 for Leioghnatus equulus and 11.97 for Gafrarium tumidum in Untia.

Thus, fish and shellfish consumption become very risky for community. Arsenic exposure impact carcinogenic and non-carcinogenic risk because all risk characterization were above the safe limit. They necessary to control the exposure pathway, intake, fish and shellfish sustainable consumption frequency. 
Table 3. Level of Carcinogenic Risk (ECR) and Non-Carcinogenic Risk (RQ) Arsenic (As) by Fish and Shellfish Consumption $(\mathrm{Dt}=30$ years $)$ from Kaluku Bodoa and Untia Community

\begin{tabular}{|c|c|c|c|c|c|}
\hline \multirow[t]{2}{*}{ Risk type } & \multirow[t]{2}{*}{ Location } & \multirow[t]{2}{*}{ Fish /shellfish species } & \multicolumn{3}{|c|}{$\begin{array}{l}\text { Carcinogenic Risk (ECR) level / Non- } \\
\text { carcinogenic (RQ) riskLevel }\end{array}$} \\
\hline & & & Mean & Min & Maks \\
\hline \multirow{3}{*}{ Carcinogenic } & & Fish & & & \\
\hline & Kaluku Bodoa & Siganus sp. & $1.19 \mathrm{E}-03$ & 4.71E-04 & $2.50 \mathrm{E}-03$ \\
\hline & Untia & $\begin{array}{l}\text { Leiognatus equulus } \\
\text { Shellfish }\end{array}$ & $1.10 \mathrm{E}-03$ & $3.42 \mathrm{E}-04$ & $2.14 \mathrm{E}-03$ \\
\hline \multirow{6}{*}{ Non-Carcinogenic } & Kaluku Bodoa & Anadara grandis & $2.20 \mathrm{E}-03$ & 0 & $5.43 \mathrm{E}-03$ \\
\hline & Untia & $\begin{array}{l}\text { Gafrarium tumidum } \\
\text { Fish }\end{array}$ & $2.31 \mathrm{E}-03$ & 0 & $4.01 \mathrm{E}-03$ \\
\hline & Kaluku Bodoa & Siganus sp. & 6.2 & 2.44 & 12.95 \\
\hline & Untia & $\begin{array}{l}\text { Leiognatus equulus } \\
\text { Shellfish }\end{array}$ & 5.71 & 1.77 & 11.09 \\
\hline & Kaluku Bodoa & Anadara grandis & 11.42 & 0 & 28.14 \\
\hline & Untia & Gafrarium tumidum & 11.97 & 0 & 20.8 \\
\hline
\end{tabular}

Source : Primary data

Organ target toxicity of arsenic were the nervous, heart, endocrine system, and haematopoietic system. The toxic effect of arsenic especially depending on the species, oxidation states and chemistry. Inorganic arsenic was considered carcinogenic and relate primarily to the lungs, kidneys, bladder, and skin disorders [1]. The evidence, people who eat fish, rice, and drinking water containing arsenic can experience systemic effect (dermal effect), immunological and lymphoreticular effects (cellular limpatik), neurological effects, reproductive effects, developmental effects, and cancer [22-23].

The findings in this study supported with other previous study [6], which showed that long-term arsenic exposure in Buyat residents who consume fish and rice had a significant relationship with an increased incidence of skin disorders or hyperkeratosis. Skin disorders as a result of exposure determinants of oral arsenic through biota such as fish from the groundwater was polluted by heavy metals arsenic. The other study also confirmed by a research report that inorganic arsenic through the ingestion can affect various effects such as dermal; hyperkeratosis, hyperpigmentation and hypopigmentation; periorbital swelling; the occurrence of spontaneous abortion and nervous system damage (if in high doses) [23-25].

Arsenic can be easily absorbed roughly 95 percent if it swallowed. Arsenic will distributedand stored in all tissues of the body and metabolized and eliminated through two sequential process. The first was the oxidation/reduction were arsenate into arsenite and arsenite into arsenate. Reduction of arsenate (As V) to arsenite (As III) required before methylation occurs. This reaction requires glutathione (GSH). Glutathione was known to form complexes with arsenic and mediates the reduction of arsenate into arsenite. Glutathione complex can be eliminated in the bile and a positive correlation has been found between glutathione and arsenic in the bile [22-23].

The second stage was the metilation, which occurs mainly in the liver, require s-adenosymetionin (SAMe) and possibly other methyl donors (choline, cysteine, glutathione, lipoic acid reduced) to produce monometilarsenic acid (MMA) and dimetilarsenic acid (DMA). Both MMA and DMA are found in human urine and are expected as the end product of the metabolism of arsenic. Because DMA was removed from the cell faster than MMA or inorganic arsenic, and arsenic methylation reduces the amount retained in the tissues by the increased solubility in water arsenite, methylation was considered by some researchers as a mechanism detoxication [16], [22]. Speciation studies of human exposure to arsenic in the urine indicates that the metabolite was composed of $10-15 \%$ inorganic arsenic and acid monomethylarsenic and most (60-80\%) of dimetilarsenic acid [13].

The risk level of carcinogenic and non-carcinogenic caused by fish and shellfish consumption contain Arsenic showing signs of insecurity so they were need required risk management. Risk management was done in an effort to reduce of health risk for locally and systemically effect. There are several ways to reduce levels (C) of arsenic in fish and shellfish, such us reducing the intake (R) fish and shellfish rate, reducing the frequency of arsenic exposure (FE) and reducing the duration of arsenic exposure (Dt).

\section{CONCLUSION}

The higher mean levels of Arsenic (As) in fish and shellfish consumed by communities were found in Untia than Kaluku Bodoa coastal areas. Carcinogenic risk level value was more than exponent 4 (ECR > E-4) and non-carcinogenic risk more than $1(\mathrm{RQ}>1)$ at all study sites. It can be concluded that fish and shellfish were not safe for consumption and impact health problems that are non-carcinogenic even carcinogenic. Risk management need to be control it. We recommended that people, especially community 
who settled in the Kaluku Bodoa and Untia coastal always restrict the daily consumption offish and shellfish by reducing the intake rate of fish and shellfish, reducing levels of arsenic during the food processing, as well as reducing the frequency of As exposure (fE) and the default duration time of arsenicexposure (Dt).

\section{ACKNOWLEDGEMENTS}

Authors highly appreciate and would like to thank for the Makassar Municipality who have given a very kind cooperation during the research commencement. Hence, we thank to National Chemical Laboratory Standardizationin Maros Research Center for Food Technology, Environmental Agency of Makassar Regions, and the District Health Office of Makassar, Indonesia for their supporting and assistance during data collection and analysis.

\section{REFERENCES}

[1] W. Widowati, et al., "The Effects of Toxic Metals: Pollution Prevention and Control," Yogyakarta, Andi Offset; 2008.

[2] Rompas, "Toxicology Marine: Marine Board Secretariat," East Jakarta, Walau Benkulen, 2010.

[3] Bhupander P. and Mukherjee D. P., "Assessment of Human Health Risk for Arsenic, Copper, Nickel, Mercury and Zinc in Fish Collected from Tropical Wetlands in India," Adv Life Sci Technol, vol. 2, 2011. Available from: http://www.iiste.org/Journals/index.php/ALST/article/viewFile/961/882.

[4] Food and Drug Administrationof Indonesia Regulations, "Determination Limit of Microbial Contamination and Chemicals in Food," 2009. No. HK.00.06.1.52.4011.

[5] A. Daud, et al., "Risk Management of Cadmium (Cd), due to Leiognatohus sp., Portunus Pelagicus, Anadara sp., dan Penaeus, sp.,Consumption Among Community in Tallo Subdistrict, Makassar, Indonesia," Interrnational J Sci Res Publ., vol/issue: 3(11), 2013.

[6] Daud A., "Material Pollutants Arsenic in Blood and Urine as a Hyperkeratosis Biomarkers at Buyat Community," Makassar, University of Hasanuddin, 2009.

[7] Daud A., "Heavy Metal Toxicology of Arsenic in Environmental Risk Health Analyze Perspectives," Makassar, University of Hasanuddin, 2014.

[8] IRIS, “Arsenic Inorganic,” 2010. Available from: http://www.epa.gov/iris/subst/0278.htm.

[9] South Sulawesi Provincial Government, "Quality Standards and Environmental Damage Criteria," The South Sulawesi Governor Standard Regulations No. 69. South Sulawesi Provincial Government, 2010.

[10] The Center for Health and Occupational Safety of Makassar, "Marine Water Quality Inspection for Makassar Report," The Center for Health and Occupational Safety of Makassar, 2012.

[11] Darmono, "Environment and Pollution: its Relation to Toxicological of Metal Compounds," Jakarta, University of Indonesia Press, 2010.

[12] Tahir A., "Ecotoxicology in the Health Perspective of Marine Ecosystems," Bandung, Karya Putra Darwati, 2012.

[13] P. Bhattacharya, et al., "Arsenic in the environment: Biology and Chemistry," Sci Total Environ, vol. 379, pp. 109120.

[14] Junaidi I., "Cancer,” Jakarta, Bhuana Popular Science, 2007.

[15] C. Uneyama, et al., "Arsenic in Various Foods: Cumulative Data," Food Addit Contam, vol. 24, pp. 447-534, 2007.

[16] P. A. Singh, et al., "Mechanism Pertaining to Arsenic Toxicity," 2011.

[17] Rahman A., "Instructional of Health Risk Analyze Materials Training," Intensive Basic Level Programme, Depok, 2007.

[18] The Indonesian National Standard, "Limit for Heavy Metal Contamination in Food," The National Standardization Agency, 2009.

[19] Petersen J. and Christensen B. T., "Ecotoxicological Evaluation of As, Cd, Cr, $\mathrm{Pb}, \mathrm{Hg}$ and Ni Applied with Fertilisers in Denmark," Internal report nr DJF Rapport Markbrug, pp. 98, 2009.

[20] A. Mallongi and A. L. Rantetampang, "Risks Assessment of Cadmium through Aquatic Biota Consumption from Sentani Lake in Papua, Indonesia," Int J Eng Res Technol, vol/issue: 2(6), pp. 2492-2500, 2013.

[21] The General Directorate of Environmental Health and Control Diseases, "Guidelines for Environmental Health Risk Analysis," Jakarta, Ministry of Health, 2012.

[22] "Case Studies in Environmental Medicine: Arsenic Toxicity," Agency for Toxic Substances and Disease Registry. Available from: http://www.atsdr.cdc.gov/csem/arsenic/docs/arsenic.pdf.

[23] V. Mudgal, et al., "Effect of Toxic Metals on Human Health," Open Nutraceuticals J., vol. 3, pp. 94-99, 2010.

[24] C. Vieira, et al., "Mercury, Cadmium, Lead and Arsenic Levels in Three Pelagic Fish Species from the Atlantic Ocean: Intra- and Inter-Specific Variability and Human Health Risks For Consumption," Food Chem Toxicol., vol. 49, pp. 923-932, 2011.

[25] Krishna P. V., et al., "Human Health Risk Assessment ofHeavy Metal Accumulation through Fish Consumption, from Machilipatnam Coast, Andhra Pradesh, India," Int Res J Public Environ Heal, vol/issue: 1(5), pp. 121-125, 2014. 